\begin{tabular}{c} 
International Journal of Engineering \& Technology, $7(3.21)(2018) 345-350$ \\
International Journal of Engineering \& Technology \\
SPC \\
Website: $\frac{\text { www.sciencepubco.com/index.php/IJET }}{\text { Research paper }}$ \\
\hline
\end{tabular}

\title{
The Role of Asian International Arbitration Centre (AIAC) as a regional Hub for Oil and Gas Sector
}

\author{
Wan M. Zulhafiz ${ }^{1 *}$ \\ ${ }^{I}$ Ahmad Ibrahim Kulliyyah of Laws, International Islamic University Malaysia \\ *Corresponding author E-mail: wzulhafiz@iium.edu.my
}

\begin{abstract}
Hydrocarbons projects involve multiple parties, including sovereign states and corporations, to operate expensive, complex and high-risk activities. Alternative dispute resolution (ADR) is often preferred more by the parties than litigation to ensure the smooth running of the projects. ADR refers to all mechanisms of dispute settlement other than litigation such as negotiation, mediation, adjudication, and arbitration. The Asian International Arbitration Centre (AIAC) or formerly known as the Kuala Lumpur Regional Centre for Arbitration (KLRCA) is the main institution that administers and resolves all commercial arbitration disputes in Malaysia. This research argues that, due to the technicalities and complexity of operations in the oil and gas sector, there is a need to set up a special arbitration centre for oil and gas under the AIAC to handle and resolve the industrial disputes. Furthermore, by establishing the centre, it can help to promote the AIAC as the choice of arbitration hub, especially within the Organization of the Petroleum Exporting Countries (OPEC). In doing so, it is necessary to pass a special legal framework to enable the establishment of the centre. It may function as a roadmap by the key players of the oil and gas sector to recourse in resolving disputes. The methodology employed by this research is carried out in a prescriptive, comparative and analytic manner.
\end{abstract}

Keywords: Dispute resolution; oil and gas; arbitration

\section{Introduction}

Hydrocarbons projects involve multiple parties, including sovereign states and corporations, to operate complex, costly, high-risk jobs (1). In this context, the oil and gas sector is exposed to various types of disputes such as international maritime boundary claims, claims over jurisdiction, expert determination, environmental claims, regulatory issues, and trade restriction $(2,3)$. Alternative dispute resolution (ADR) is often preferred more by the parties than litigation to ensure the smooth running of the projects. The Asian International Arbitration Centre (AIAC) or formerly known as the Kuala Lumpur Regional Centre for Arbitration (KLRCA) is the main institution that administers and resolves all commercial arbitration disputes in Malaysia. However, it may be argued that, given the technical nature and complexity of disputes that may arise in the oil and gas sectors (4), there is a need to set up an independent arbitration centre for oil and gas under the AIAC to resolve the matters.

This paper investigates the problem ADR in Malaysia, particularly in the oil and gas industry and considers what legal mechanism ought to be implemented to solve the problem. It also aims to address the problems and legal issues arising from Alternative Dispute Resolution (ADR) in the petroleum industry in Malaysia. The paper proposes a new legal framework special legal framework to enable the establishment of the centre by drawing inspiration from other jurisdiction.

\section{Literature review}

\subsection{Dispute Resolution in the Oil and Gas Industry: An Overview}

There are unique features in respect of the settlement of disputes in the oil and gas industry as explained by (4),

"...dispute resolution processes are used imaginatively in the oil and gas industry and close attention is paid to the choice of process appropriate to the dispute. This is influenced by a number of factors: need, preference and, above all, commercial intuition. There is a need for processes that are fast, effective, and cause minimum disruption to working processes and relationships. The preference is for processes which are both private and flexible. They require to be capable of crossing both international boundaries and business cultures. While, traditionally, there has been a limited pool of industry players, they have operated within a global marketplace. These factors combined to create an incentive to avoid making future enemies out of the present dispute, and drew into the range of choices the dispute resolution experiences and preferences of many nationalities and professions. As the industry has matured and expanded over time, slightly more willingness to use adversarial methods has become evident, driven less by regard for long-term relationships and more by desire for court-ordered enforceable remedies and perceived speed of return".

The parties in oil and gas industry prefer to resolve the dispute by way of an Alternative Dispute Resolution (ADR) (or it is known as Agreed Dispute Resolution in some jurisdictions) processes rather than bringing up those issues to national courts (5). In this context, the ADR refers to "all means of dispute settlement other than litigation which includes mediation, arbitration, expert de- 
termination, negotiations, conciliation" (6). There are few advantages of ADR including arbitration such as,

"quick, efficient resolution of disputes; lower legal fees; minimal pre-hearing discovery and motions; neutrality of the forum is permitted, which is particularly attractive in a multinational dispute where any participant may be reluctant to resolve disputes in one participant's home country; arbitrators can be selected who have expertise over highly technical and complicated subject matter; one party cannot force dispute resolution into a local court; flexible and informal proceedings; and the privacy and confidentiality of proceedings" (7).

Having said that,

"these advantages only exist to the extent they are preserved in the arbitration clauses drafted for the contract, and to the extent the arbitration clauses are not challenged by litigation. In addition, foreign arbitration awards can be enforced easier under various conventions and bilateral treaties than is the case for enforcement of foreign judgments"(7).

Litigation, arbitration, and expert determination are typically used by parties in oil and gas contracts as binding methods of dispute resolution mechanisms. While using any of the dispute resolutions, it is important to ensure that it does not affect the commercial activities or permanently destroy the goodwill or sour the relation-ship and future cooperation between the parties. In this regard, arbitration is seen as a better form of dispute resolution mechanisms as opposed to litigation. It is claimed that the arbitration process is more user-friendly than the litigation and its confidentiality is well preserved since the whole process is done in private and away from the public eye (8). Such aspect is considered to be very crucial in the oil and gas industry.

Besides, it also allows the parties to sense that they will be able to resolve the dispute in a fair, neutral and an independent environment (9). The disputing parties are given the right to select an arbitrator or venue depending on the contractual terms, complexity or expertise of each case (8). Moreover, the award made by the arbitrator can be enforced in countries that have ratified the United Nations Convention on Recognition and Enforcement of Foreign Arbitral Awards (The New York Convention) (1958). As mentioned earlier, the cost of arbitration is cheaper than litigation and consumes lesser time. Thus, it can be concluded that "arbitration remains the preferred mechanism for dispute settlement in the oil and gas sector"(10).

\subsection{Classification of Disputes in the Oil and Gas Indus- try}

In general, the disputes in the oil and gas industry can be divided into four categories:

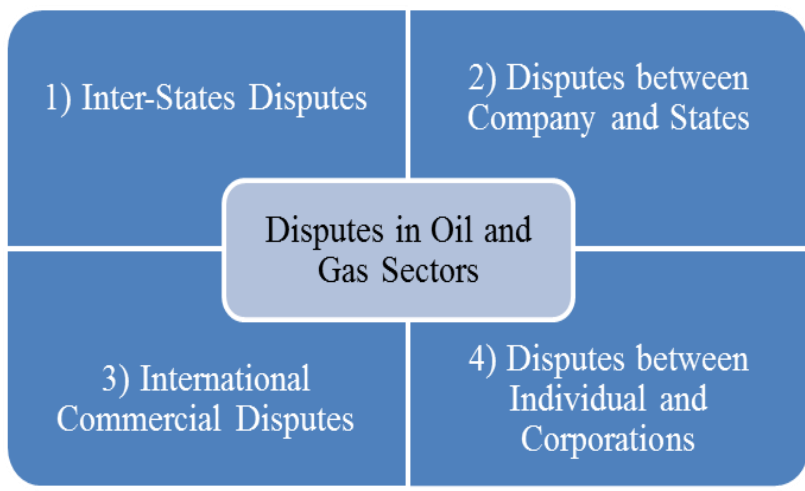

Fig. 2: Classification of Disputes in Oil and Gas Industry

Firstly, any dispute which involves inter-countries or issues concerning two or more sovereign states. For example, boundary disputes relating to oil and gas fields involving territorial sovereignty located in maritime waters. In ordinary cases, the dispute would usually include governments. However, oil and gas compa- nies may also indirectly engage with the disputes if their concession areas overlap with disputed boundary lines.

Secondly, any dispute between company and state. It is also known as state investment or investor-state disputes. The conflicts happen when a particular state varies the terms and conditions of the original agreements significantly or nationalise or expropriate an investment. "The investor (in this case, an oil and gas company or a consortium of oil and gas companies) can base its claim on its investment contract (e.g., a production sharing contract (PSC) or risk service agreement (RSA)) or an investment treaty, or possibly both" (11). In respect of the treaty claims, they are made base on bilateral investment treaties (BITs) which were entered by two sovereign states that had negotiated and ratified it. On that point, companies should ensure that their investments are protected by the BITs, and they must have access to the International Centre for the Settlement of Investment Disputes (ICSID) to resolve any dispute with a sovereign state. This could be done by incorporating an ICSID dispute resolution clause in their host government contract. Thus, it is suggested that a company should seek legal guidance in structuring their investments and how to draft the dispute resolution provisions in their host government agreements (11).

Thirdly, any dispute which involves two companies. It is also known as international commercial disputes. The dispute can be further divided into two types. The first one is amongst members of a joint venture in contracts "such as Joint Operating Agreements, Unitization Agreements, Farmout Agreements, Area of Mutual Interest Agreements, Study and Bid Agreements, Sale and Purchase Agreements, Confidentiality Agreements" (11). The second type is the dispute which occurs between operators and oilfield service contractors under various kinds of contracts, such as, Drilling and Well Service Agreements, Seismic Contracts, Construction Contracts, Equipment and Facilities Contracts, Transportation and Processing Contracts (11). It is said that "these disputes make up the majority of disputes in which oil and gas companies find themselves" (11).

Finally, any dispute between individuals and corporations. The dispute might happen in some situations; usually when people initiate legal action against oil and gas companies. For example, claim made by an individual for tortious liability and contractual claims by a consultant to demand payments from oil and gas companies.

It is worth noting that "any international contract signed by the parties that does not contain an arbitration clause will have recourse to foreign court systems to resolve their disputes" (3). Therefore, it is essential for contracting parties to incorporate an appropriate arbitration clause into their contracts. This will provide the parties with an "opportunity of resolving any disputes that may arise in future on a neutral ground rather than on the home grounds of one party or the other" (12).

\section{Methodology}

The methodology employed in this research will essentially be a combination of functional comparative analysis and doctrinal study. It is necessary to engage in a comparative analysis with the practice from other states, such as the United Kingdom, Norway, Netherlands, European Union and United States jurisdictions. Such comparative analysis would allow this research to determine which approach would be the most appropriate for the Malaysian oil and gas industry. These jurisdictions are chosen because of their frequent use as the 'applicable law' governing international oil and gas contracts. Furthermore, a comparison of the practice in these legal regimes with the Malaysian system presents an opportunity to make an original contribution to legal scholarship (13). The second methodology is a doctrinal analysis. It is based on a mix of primary and secondary data, which is taken from several sources. Primary sources of data will be the case laws of the respective jurisdictions, as well as, the statutory laws and treaties, 
which include but are not limited to the New York Convention on the Recognition and Enforcement of Foreign Arbitral Awards 1958, the Malaysian Arbitration Act 2005, the UNCITRAL Model Law on International Commercial Arbitration 198 and the Malaysian Construction Industry Payment and Adjudication Act 2012. Secondary sources of data are textbooks, journals, newspaper articles and online databases such as Lexis-Nexis, HeinOnline, Westlaw, and others.

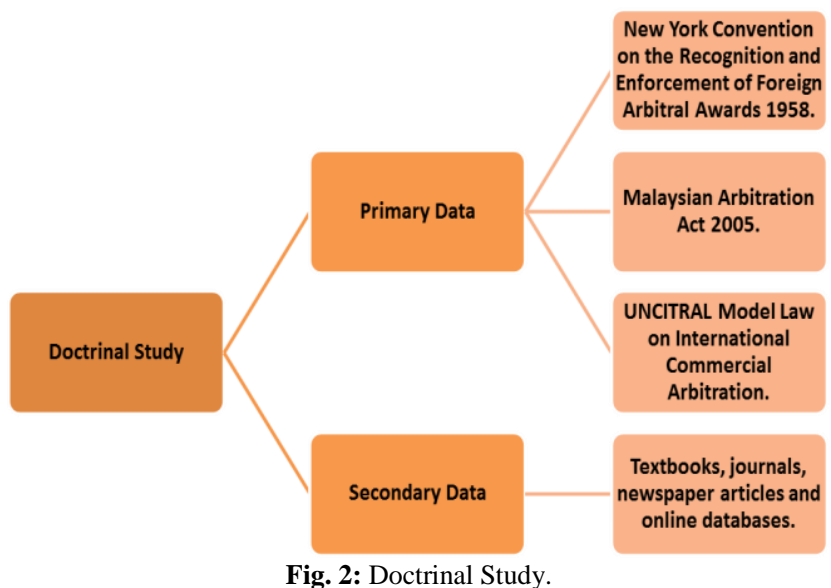

\section{Results and Findings}

\subsection{ADR in Malaysia}

Malaysia is a signatory to the New York Convention on the Recognition and Enforcement of Foreign Arbitral Awards 1958 (14). Any arbitral awards rendered in Malaysia are enforceable in more than 148 countries whom the signatories to this treaty. That said, arbitral awards are not binding in countries that are yet to ratify the Convention. In that regard, arbitration might not be a preferred choice to resolve the dispute via arbitration in those cases.

Arbitration is becoming more prevalent as an attractive option of dispute resolution forum in Malaysia. It was originally used to resolve the dispute in the construction industry and becoming increasingly popular for other commercial dispute including oil and gas sector (15).

The Malaysian Arbitration Act 2005 (MAA) is closely modelled on the UNCITRAL Model Law on International Commercial Arbitration 1985 with some amendments in 2006 and the New Zealand Arbitration Act 1996 (14). The MAA "repealed the old and out-dated Arbitration Act 1952 which had been based almost word for word on the old English Arbitration Act 1950" (16). Such repeal "has increased public confidence in, and adoption of, the arbitral process" (12). Malaysia is a common law jurisdiction, any decisions made by Commonwealth courts, especially in commercial matters, would be regarded as highly persuasive (12).

The principal institution that both administers and commonly provides a venue for commercial arbitration in Malaysia is the Kuala Lumpur Regional Centre for Arbitration (KLRCA) (14). The AIAC is "internationally recognised as an experienced, neutral, efficient and reliable dispute resolution service provider" (17). It provides a forum to resolve disputes pertaining to trade, commerce, and investment.

"The [AIAC] was established in 1978 under the auspices of the Asian-African Legal Consultative Organization. The [AIAC] was the first regional centre established in Asia to provide institutional support as a neutral and independent venue for the conduct of domestic and international arbitration proceedings in Asia. It was also the first centre in the world to adopt the UNCITRAL Arbitration Rules as revised in 2010. The [AIAC] has developed new rules to cater for the growing demands of the global business community, such as the [AIAC] i-Arbitration Rules and the AIAC
Fast Track Rules, as well as Mediation and Conciliation Rules" (12).

Besides the AIAC, arbitrations are also administered by some other professional bodies, such as the Institute of Engineers Malaysia, Kuala Lumpur (IEM) and the Malaysian International Chamber of Commerce and the Malaysia Institute of Architects (Pertubuhan Akitek Malaysia) (PAM).

"The IEM was formed in 1959 and was admitted as a member of the Commonwealth Engineers Council in 1962. The Institution is a qualifying body for professional engineers in Malaysia. It appoints arbitrators when the contract used by the parties is an IEM standard term contract. In addition to arbitration, it administers other forms of alternative dispute resolution (ADR)" (17).

On the other hand,

"PAM was originally established as the Institute of Architects Malaya (IAM) in 1920. PAM was registered with the Registrar of Societies Malaysia on 20 January 1967 under the present constitution. PAM is the governing body for engineers. It appoints arbitrators when the contract used by the parties is a PAM standard term contract. In addition to arbitration it administers other forms of ADR" (17).

Apart from the IEM and PAM, other related bodies are like Selangor Chinese Chamber of Commerce, Malaysian Rubber Board, Palm Oil Refiners Association of Malaysia, Institution of Surveyors, the Malaysian International Chambers of Commerce. However, it is important to note that none of these bodies are connected to the oil and gas sectors in particular. Hence, it could be regarded as one of the flaws of the AIAC to resolve matters pertaining to oil and gas.

In 2012, Construction Industry Payment and Adjudication Act 2012 (CIPAA) was passed to mandate adjudication in construction-related disputes to reduce numbers of arbitration cases. The CIPAA applies to all construction agreements, both domestic and international contracts carried out in Malaysia. 'Construction work' is defined broadly, includes water, gas, oil and petrochemical works. The broad definition of "construction" under CIPAA provides a better room of ADR for oil and gas disputes in Malaysia. Unlike the UK, the definition of construction excludes oil and gas activities. This could be considered another plus point for Malaysia to promote the AIAC as a choice hub for dispute resolution in the oil and gas sectors at the international level.

\subsection{ADR Cases Involving Oil and Gas Matters in Other Jurisdictions}

When discussing the issue of ADR in the oil and gas industry, it is vital to look into the outlooks of ADR in other foreign jurisdictions. This is because, more often than not, contracts in the oil and gas industry involve foreign parties and international players (3).

One of the unique features makes arbitration popular is because the arbitral tribunal decision is recognised and enforceable internationally. In other words, "the enforcement does not only take place in the place where the award is made but also in any other country where the party against whom the award was made has his assets" (3).

For example, in 1933, the Arabian American Oil Company (Aramco) signed an agreement with the Saudi Arabian government. The agreement stipulated that the exclusive right was granted to Aramco to extract and transport oil from the concession block in Saudi Arabia. Later in 1954, the government of Saudi Arabia and Saudi Arabian Maritime Tankers Ltd signed another contract that was inconsistent with the earlier agreement which had resulted in a dispute between the parties. However, the dispute was managed to be resolved by arbitration in Geneva, 1955 (18).

In another case, the dispute involving government of Libya, British Petroleum (BP), Texaco Overseas Petroleum Company (TOP$\mathrm{CO}$ ) and Libyan American Oil Company (LIACO) regarding the nationalization phenomenon in Libya was settled through international arbitration on the 7th December 1971. 
In 2007, an arbitration award of ICC ruling was enforced between Exxon Mobil and Petroleos De Venezuela, S.A. (PDVSAVenezuela NOC). The dispute was about the 2007 nationalization of assets by the Venezuelan government in which Exxon Mobil was awarded $\$ 908$ million; however, the award was finally reduced to around $\$ 750$ million in favour of PDVSA.

Most of the countries have set up their arbitral institution and drafted their arbitration rules to accommodate parties to an arbitration agreement to settle their commercial disputes. Some of the institutions, to name a few such as, American Arbitration Association (AAA), the Euro-Arab Chambers of Commerce (EACC), the London Court of International Arbitration (LCIA), the Netherlands Arbitration Institute (NAI), the Stockholm Chamber of Commerce (SCC), the International Court of Arbitration (ICC), the United Nations Commission on International Trade Law (UNCITRAL), have come out with their own set of rules to oversee the conduct of arbitration (2). Any dispute that has been brought up to the respective arbitration institution shall be resolved by its rules and regulation.

\section{United Kingdom}

In the United Kingdom, "English courts, in particular, are now willing to take a more aggressive approach while deciding the outcome of disputes in which ADR has been refused unreasonably by disputants" (8). This can be seen in a landmark case of Susan Dunnett v. Railtrack Plc [2002] EWCA Civ 303, [2002] 1 WLR 2434, [2002] CPLR 309, [2002] 2 All ER 850, where this case has set a precedent for any opponents, who seek to neglect ADR. It was held that the parties should recourse to all available mechanisms of ADR as appropriate prerequisites before the parties proceed to litigation.

\section{Netherlands}

Meanwhile, in the Netherlands, a settlement conference is used as a primary stage in civil litigation where the judge will deliver a high steer on the merits of the dispute (6). Such requirement has been made mandatory across the courts in Netherlands especially if it seems that "the litigation process will not in itself be able to determine all aspects of the dispute between the parties" (4).

\section{USA and Norway}

In some parts of the USA and also Norway, under particular circumstances, mediation is required by legislation as pre-condition prior to holding adjudication in the local courts. Besides, "many US states and federal courts (including appeal courts) have courtannexed or court-ordered ADR programmes that have, on evaluation, proved to be very effective" (4).

\section{European Union}

On the other hand, European Union Directive (i.e. Directive 200S/52/Ee of the European Parliament and of the Council of 21 May 2008 on certain aspects of mediation in civil and commercial matters) encourages the use of ADR in both civil and commercial matters. It sets out particulars for confidentiality and time limitation rules for litigation to stay in order to provide room for the use of ADR in the Member States. Under the EU Civil Justice programme, EU itself has funded research with regards to "the use of information in the Member States, and the cost of not using ADR in cross-state disputes" in promoting the use of ADR to its members (4).

The comparative analysis of ADR framework in the abovementioned jurisdictions can be summarised as follows:

Table.1: Comparative analysis of ADR framework in Malaysia, UK, USA, Norway, Netherland and the European Union.

\begin{tabular}{|l|l|l|}
\hline Country & ADR Framework/ Model & $\begin{array}{l}\text { Mandatory for Oil } \\
\text { and Gas Sector }\end{array}$ \\
\hline Malaysia & $\begin{array}{l}\text { United Nations Commission on } \\
\text { International Trade Law } \\
\text { (UNCITRAL) }\end{array}$ & No \\
\hline $\begin{array}{l}\text { United } \\
\text { Kingdom }\end{array}$ & $\begin{array}{l}\text { London Court of International } \\
\text { Arbitration (LCIA) }\end{array}$ & Yes \\
\hline $\begin{array}{l}\text { United } \\
\text { States }\end{array}$ & $\begin{array}{l}\text { American Arbitration Association } \\
\text { (AAA)] }\end{array}$ & Yes \\
\hline Norway & Yes & Yes \\
\hline
\end{tabular}

\begin{tabular}{|l|l|l|}
\hline Netherland & $\begin{array}{l}\text { Netherlands Arbitration Institute } \\
\text { (NAI) }\end{array}$ & Yes \\
\hline $\begin{array}{l}\text { European } \\
\text { Union }\end{array}$ & Yes & Yes \\
\hline
\end{tabular}

Based on the above discussion, it can be said that despite there is a gap of ADR legal framework pertaining to oil and gas sector in Malaysia, until now the country has no clear guidelines to resolve the complexities and technicalities of the oil and gas disputes. Moreover, unlike other jurisdictions, the ADR has not been made mandatory for oil and gas cases in Malaysia before they were brought for litigation. Hence, it is argued that there is need to establish a special legal framework in dealing with this problem.

\subsection{Special Legal Framework for Oil and Gas}

(4) argues that "given the technical nature of disputes that may arise in the oil and gas industries, some negotiations require to be carried out by a team of people who can, collectively, bring the necessary expertise (for example technical, legal, financial) to the dispute and its resolution". Moreover, taking the case of United Kingdom, (6) maintains that,

"[it is] observed that the industry has developed its own particular arrangements in terms of dispute resolution where as [dispute resolution] processes might be utilized as a means to an end of achieving strategic advantages over the other party by using the unique cultural dimensions of the industrial practices. This serves the dual purpose of avoiding litigation while at the same time avoiding a breakdown of industrial relations" (6).

On this point, there have been some initiatives implemented to bring the operators and oilfield service contractors together on a multilateral, cooperative basis using their respective industry organisations. There are several types of standard forms of conditions of contract published by various professional bodies in the UK North Sea, Canada and the international level that could be adopted as a foundation in drafting oilfield contracts, including, LOGIC (Leading Oil \& Gas Industry Competitiveness), Canadian Association of Oilwell Drilling Contractors (CAODC), Canadian Association of Petroleum Producers (CAPP), Association of Independent Petroleum Negotiators (AIPN), International Association of Drilling Contractors (IADC), International Association of Geophysical Contractors (IAGC), Petroleum Equipment Suppliers Association (PESA), International Federation of Consulting Engineers (IFCE) and several other international service organisations (19). LOGIC, for example, is widely used primarily for offshore operations in the U.K. sector of the North Sea (20). It is also used widely in Southeast Asia, including Malaysia.

LOGIC is a non-profit subsidiary of Oil \& Gas UK and its objective is to promote and ensure "United Kingdom Continental Shelf (UKCS) competitiveness remains current and was carried forward into the work of the PILOT Taskforce, a collaborative partnership of oil and gas industry operators, suppliers and the UK Government" (21). LOGIC publishes several standard forms of contracts to be used in marine construction contracts within the petroleum industry (22). The standard contract is derived from the CRINE (Cost Reduction in the New Era) initiatives, where the operators and contractors work together to produce the standard contracts for the UK Offshore Oil and Gas Industry which today are available in ten forms, four of which are second editions (23).

For construction contracts, LOGIC has produced a set of General Conditions for Marine Construction (the 'Model Construction Contract'), 2004 Edition (24). The Model Construction Contract is intended for use in an offshore context and specifically for pipe laying, offshore installation, subsea construction, and inspection, repair and maintenance operations. It is similar in overall form and content of Engineering, Procurement, Construction and Installation (EPCI) contracts, which are frequently used by operators in South/Southeast Asia to deliver 'turnkey' solutions for offshore infrastructure projects (25). Due to complexities and technicalities of the industry, it could be argued that it is necessary to have an 
individual arbitration centre for oil and gas, which consists of a team of specialists to deal with disputes pertaining to the subject.

In fact, the idea to establish a special arbitration centre for a particular sector is not something new, and it has been done before. The following are the examples of particular arbitration centre which only arbitrate specific and technical aspects of a particular subject:

i. Arab Intellectual Property Mediation and Arbitration Society (AIPMAS) - Amman, Jordan;

ii. Court of Arbitration for Sport - Lausanne, Switzerland;

iii. Energy Arbitration Court (EAVB) - Budapest, Hungary;

iv. European Centre for Financial Dispute Resolution (EUROARBITRATION) - Paris, France;

v. Foreign Trade Court of Arbitration at the Serbian Chamber of Commerce - Belgrade, Serbia;

vi. Insurance and Reinsurance Arbitration Society (ARIAS) London, England;

vii. Muslim Arbitration Tribunal (MAT) - London, England;

viii. World Intellectual Property Organisation Arbitration and Mediation Centre (WIPO) - Geneva, Switzerland

ix. Dispute Resolution Center of the Federal Association of Engineers and Architects of Costa Rica - San José, Costa Rica;

x. General Arbitration Tribunal of the Buenos Aires Stock Exchange (BCBA) - Buenos Aires, Argentina;

xi. Equine Dispute Resolution (EqADR) - Lexington, USA;

xii. China Maritime Arbitration Commission (CMAC) - Beijing, China;

xiii. Singapore Chamber of Maritime Arbitration (SCMA) - Singapore, Singapore;

xiv. Tokyo Maritime Arbitration Commission of the Japan Shipping Exchange (JSE) - Tokyo, Japan; and

xv. Maritime Arbitrators Association of Nigeria (MANN) - Lagos, Nigeria.

The abovementioned arbitration centres were established to facilitate the complexity of technical subject according to its respective discipline. These 15 arbitration entities can be divided into ten categories as far as their subjective jurisdictions are concerned: Maritime (four entities), sports (two entities), stock exchange (one), engineering and architecture (one), intellectual property (two), and finally Muslim disputes, insurance and reinsurance, foreign trade, financial and energy disputes each have only one arbitration entity. Even though the Energy Arbitration Court (EAVB) is already in existence, the proposed arbitration centre for oil and gas will be different from the EAVB regarding subject matter, structure and dispute resolution mechanism.

While it is true that generally, "arbitration centers, tribunals or even courts handle all the cases referred to them without limiting the scope of the subjects handled by them" (26), it is argued that due to the complexity of technical subject of the oil and gas sector there is a need to set up a special arbitration centre to resolve the disputes which will be placed under the AIAC.

Based on one previous study, when respondents were asked about their preferred institutions, it was "revealed that institutions are primarily chosen due to their high level of administration, neutrality/internationalism and ability to administer arbitrations worldwide" (27). In that sense, it could be argued that Malaysia, particularly the AIAC has strong potential to be chosen as a preferred arbitration institution for its neutrality and international-ism. The reason is that Malaysia, on the one hand, is a competitive global player in terms of international trade and business. While, on the contrary, it is not a member of OPEC countries. These factors considered as bonus points to the AIAC.

It is claimed that "the growth of emerging markets in Asia has created a flow of capital between west and east - often to fund significant oil and gas projects and mega infrastructure developments" (27). These commercial activities have given an enormous impact on the use of arbitration in Asia for large oil and gas projects (27). Therefore, by establishing the special arbitration centre it will help to promote the AIAC as the choice of arbitration hub, especially within the oil-producing countries such as Saudi Arabia Kuwait, Canada, United Arab Emirates, and other Organization of the Petroleum Exporting Countries (OPEC).

\section{Conclusion}

In conclusion, whilst Malaysia is profoundly depending on the resources from the oil and gas, it is exceptionally significant that both local and foreign industry players who undertake the project in Malaysia will be assured "with a fast, cost-effective and efficient manner in which to resolve their disputes which inevitably arise from time to time" (9). This is because, while it is true that despite the obvious advantages of alternative dispute resolution (ADR) in the oil and gas industry in maintaining the smooth running of commercial activities both at national and international levels, the impression that the use of ADR could save time and cost might turn out to be an exaggerated in the absence of a clear legal framework. Some parties had even unwillingly opted the $\mathrm{ADR}$ as a mechanism to resolve their contractual disputes due to the industrial pressure rather than expecting to save cost and time. This is because, as of now, there are no clear guidelines in resolving the complexities and technicalities of the oil and gas disputes, not to mention, if the cases are urgent matters. As a result, the process can take a longer period more than expected. The problem leads "to the conclusion that despite being the lesser evil for a firm facing the horrors of expensive and time-consuming litigation, the arbitration mechanisms in place today and the way they are used are less than perfect when catering to the needs of the major industry players in the oil and gas market today" (6).

Despite the existence of legal framework embracing alternative dispute resolution which has been already in place, it is argued that the current legal framework is not comprehensive to resolve matters pertaining to oil and gas disputes in Malaysia. A special legal framework is needed to establish a special centre for oil and gas as a roadmap for the industry key players in solving their dispute. The centre "should include an independent arbitration and supervisory body as an indispensable component for settlement of disputes in oil industry contracts" (26). In order to promote AIAC as a choice of international arbitration hub by foreign industry players in the oil and gas sector, it is essential to encourage the development of an effective ADR framework which to be supported by a special arbitration centre for oil and gas in providing a forum for dispute resolutions, especially that involve complexities and technicalities of the subject matter.

Recently, numbers of the arbitral institution have amended their rule to allow for an emergency relief. The emergency relief is designed to handle urgent matters which cannot envisage for the constitution of the tribunal. "Unlike the equivalent regimes of other arbitral institutions, the ICC emergency arbitrator procedure can be invoked before a request for arbitration is filed" (4). That said, despite the use of emergency arbitration procedure, there is some limitation in the process, such as numbers of concerns were raised with regards to its enforcement and recognition of the arbitral award. In the United Kingdom for example, since "the emergency arbitrator procedure is still relatively new and untested in England, and internationally, it is critical that international oil and gas/energy companies are aware of the risks and uncertainties involved before embarking on this route in preference to seeking court assistance" (28). It is argued that due to the complexity of the technical subject of the oil and gas sector, there is a need to establish a new legal framework to handle the disputes, particularly in Malaysia.

The new legal framework provides a unique perspective into the application of international and local arbitration laws in respect of the complexities of the upstream, midstream and downstream sectors of the oil and gas industry. It specifically focuses on the technical nature of disputes which arises in the oil and gas industries. The new legal framework proposes to set up an exclusive centre for arbitration for the oil and gas industry by drawing inspi- 
ration from other jurisdictions such as the United Kingdom and the United States. Such arbitration centre will be placed under the AIAC. Moreover, it will also help to promote the AIAC as the choice of arbitration hub especially for matters pertaining to oil and gas disputes.

An empirical legal scholarship will be adopted for future research. The purpose of the empirical study is to examine the current practice of alternative dispute resolution pertaining to oil and gas issues in Malaysia. In conducting the empirical study, semistructured interviews will be conducted with the key players in the Malaysian oil and gas industry. The empirical evidence will illustrate the reality of alternative dispute resolution practice, such as negotiation, mediation, adjudication and arbitration in the oil and gas industry in Malaysia.

\section{References}

[1] Zulhafiz WM. Recent Trends in Allocation of Risk Post-Macondo: the Growing Tension Between Oil and Gas Standard Forms of Contract, and Contractual Practice. International Energy Law Review. 2017(5):174-

[2] Zulhafiz WM. On the Contractual Risk Allocation in Oil and Gas Projects. The Law Review. 2017(2):168-

[3] Nammei Luki B, Abubakar N-J. Dispute Settlement in the Oil and Gas Industry: Why is International Arbitration Important? Journal of Energy Technologies and Policy. 2016;6(4):30-

[4] Ross M. Dispute Management and Resolution. In: Gordon G Paterson J, Üşenmez E, editors.: Dundee University Press; 2010. p. 632-.

[5] Mgaya RB. Dispute Resolution in Oil and Gas Industry: International Commercial Arbitration.

[6] Maluka AZ. Dispute Resolution in the Oil and Gas Industry. 2010.

[7] Hoffman SL. The Law and Business of International Project Finance third edition. 3rd ed: CUP; 2008.

[8] Waqas M. Dispute Resolution in Oil And Gas. Oil \& Gas Financial Journal. 2015;12(1)

[9] Rahman AJ, editor Developments in Arbitration and Mediation as Alternative Dispute Mechanisms in Brunei Darussalam2013 2013: University of Queensland, Brisbane.

[10] Arbitration preferred method of dispute settlement - Conclusions from LCIA's ground-breaking debate at Oil and Gas Sector Sympos (LCIA - London Court of International Arbitration). 2016 $10 / /$.

[11] Martin AT. Dispute resolution in the international energy sector: an overview. The Journal of World Energy Law \& Business. 2011;4(4):332-68

[12] Nadkarni N, Singh D. Malaysia: An Overview Of Arbitration In Malaysia. 2016

[13] Zulhafiz WM. A Comparative Analysis on the Enforceability of Knock-for-Knock Indemnities in Thailand and the United Kingdom. Journal of Malaysian and Comparative Law. 2017;44(1)

[14] Schütze RA. Institutional Arbitration: A Commentary: Bloomsbury Publishing; 2013. 1200- $\mathrm{p}$

[15] Bukhari KZ. Arbitration and Mediation in Malaysia.

[16] Nathan RS. Arbitration procedures and practice in Malaysia: overview. 2016

[17] Ranai AKM. Arbitration procedures and practice in Malaysia: overview. 2011

[18] Cameron PD. International Energy Investment Law: The Pursuit of Stability: Oxford University Press; 2010. 499- p.

[19] Anderson OL, Lowe JS. OGEL Special Issue: Oil Spills. OGEL. 2010;8(3):1-.

[20] Moomjian CA, editor Drilling Contract Historical Development and Future Trends Post-Macondo: Reflections on a 35 Year Industry Career2012 2012: Society of Petroleum Engineers.

[21] Logic. LOGIC. 2017.

[22] Martin AT, Park JJ. Global petroleum industry model contracts revisited: Higher, faster, stronger. The Journal of World Energy Law \& Business. 2010;3(1):4-43.

[23] Franklin H. Irretrievable Breakdown? A Review of Operator/Contractor Relationships in the Offshore Oil and Gas Industry. Journal of Energy \& Natural Resources Law. 2005;23(1):1-

[24] Zulhafiz WM. Unfair Contract Terms Act 1977: does it provide a good model in regulating risk allocation provisions in oilfield contracts in Malaysia? IntJTrade and Global Markets. 2015;8(1):316.

[25] Hewitt T. An Asian Perspective on Model Oil and Gas Services Contracts. Journal of Energy \& Natural Resources Law. 2010;28(3):331-.

[26] Akhlaghi B. Lex Petrolea \& International Commercial Arbitration. 4th Bi-Monthly News \& Analysis of the International Law Office. 2014.

[27] White, Case. Oil and Gas Industry Favours International Arbitration for Dispute Resolution. 2015.

[28] Lu JJ. The emergency arbitrator: a new remedy for oil and gas disputes? Berwin Leighton Paisner. 2014:4-6. 